\title{
The Utilization of Electronic Archives as a Support for Study Employee Performance at The Customs and Excise Office Type A Semarang Customs
}

\author{
Tanty Qornia Dewi ${ }^{1}$, Yustina Erti Pravitasmara Dewi ${ }^{2}$
}

1,2 Satya Wacana Christian University, Salatiga, Indonesia

\section{ART ICLE INFO}

\section{Article history:}

Received September 02, 202

Revised September 03, 2021

Accepted October 26, 2021

Available online November 25, 2021

Keywords:

Electronic Archives, Employee, Performance

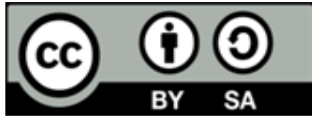

This is an open access article under the CC BY-SA license.

Copyright (@) 2021 by Author. Published by Universitas Pendidikan Ganesha.

\begin{abstract}
A B S T R A C T
Technological developments make it easier for employees to carry out work, including archive management employees. Archives undergo changes and developments in electronic form. The development of supporting technology for electronic archive management. This study aims to analyze the use of electronic records to support the effectiveness of employee performance and the factors that support employee performance. This qualitative research uses a descriptive approach. The technique used to collect data is interviews. The instrument used to collect data is a questionnaire. This study uses three stages of data analysis, namely data reduction, data presentation, and concluding. The research subject is the selected resource person, an employee with the position of Customs and Excise Inspector. The technique used to analyze the data is descriptive qualitative analysis. The results of this study indicate that the use of electronic archives supports employee performance. The benefits of using electronic archives include easy and fast use, safe, and time-saving. There are four factors supporting employee performance: the work environment, ability, motivation, and adequate facilities. Factors supporting employee performance in using electronic records are leaders who always encourage employees to learn and develop themselves and a comfortable work environment for employees, human resource capabilities, and adequate facilities and equipment provided by the institution.
\end{abstract}

\section{INTRODUCTION}

Administrative activities are unseparated from an archive creation process carried out by any institution, both public and private agencies (Alarcón-Aguirre et al., 2020; Przybyła et al., 2020). Archives produce one source of information that can record and are important in a group. If there are no archives, an administrative officer cannot remember manually and without tools all records of activities that have been done and complete documents, and manage an archive system that is in accordance with employees and other supporting media to achieve the goals of the institution (ElZahed \& Marzouk, 2022; Tray et al., 2020). The definition of archive is as a form of a collection of documents that have been stored in their entirety as they are very useful for interest and can be easily and quickly found for reused (Hodder et al., 2021; Kothari, 2021; Sreemany \& Bera, 2022). Archives is an information that is stored in various forms, including data on computers, created or received and managed by organizations as well as in business transactions, and stored as evidence of activity. The archive is a collection of documents that are stored systematically because whenever they are needed, they can be quickly found (Mufidah, 2013; Peyn \& Linke, 2018).

The term electronic archive or e-archive means a system of collecting and storing information in the form of electronic documents to be visible, managed, found, and then reused according to (Mikhail et al., 2018; Nyfantoro et al., 2020). E-archive as an archive that is created, used, and maintained as a form of proof of transactions, activities, and functions of institutions and individuals that have been transferred and then processed using a computer (Rifauddin, 2016; Triyono \& Samopa, 2013). E-archives describes the combination of conventional archives with archive storage systems on electronic media. A document can be considered as an archive if it has content or data, information or requests to be submitted (Kiklhorn et al., 2020; Rustam, 2014). Archive can be divided into some types including dynamic and static archives. Dynamic archives are archives that still have functional values in the implementation of activities, planning for implementation in daily administrative activities, and state administration (Chen et al., 2019; Liu et al., 
2019). Meanwhile, static archives are archives that are not used to carry out the planning process and the implementation in daily administration or state life. Static archives are in the state archives and regional archives

There is a distinctive difference between conventional and electronic archives. First, folders, conventional archives will be in the form of physical folders that have a function to store archive sheets and documents, but in electronic archives, the folder is in the form of a file or folder to store a document (Habiburrahman, 2016; Sholeh \& Hartono, 2018). Second, archives, in the form of hardcopy of documents in conventional archives, but in electronic archives, the document has been scanned in the form of files or images (Fauziyah, 2019; Kalinda, 2019). Third, small cabinets, in conventional archives, it is in the form of shelves for archives, whereas in electronic archives it is in the form of a virtual cabinet created with a database (Nugraha, 2019; Sugiarto, Agus \& Wahyono, 2005). In dealing with conventional archives, it is not only seen from the time, space, and cost-effectiveness, but also the security aspect of the archive. In general, human errors often occur in employees who are managing the archive process (Mufidah, 2013; Sreemany \& Bera, 2022). Besides electronic media, the effectiveness of archive management in an institution can be influenced by employees who are placed in the archives department with the facilities provided to help manage and maintain archives.

The Customs and Excise Office Type A Semarang is a government office that serves the affairs of export and import goods. This office requires important letters and documents to be stored as evidence later. After the number of data increases and accumulates, they should be collected, stored, and then processed. Management of archives is more effective now due to the use of electronic tools (Bressey, 2020; Ribka Aprilia et al., 2020; Şimşek et al., 2022). If an institution has implemented an electronic archive system, it can save workspace, as the physical storage can be replaced by computer storage. One of the uses of computers for archiving systems can change a conventional archive into a digital and electronic archive (Aryani, R., Suratno, T., Mauladi, M. \& Utomo, 2019; ElZahed \& Marzouk, 2022; Kulcu \& Cakmak, 2012). Besides working procedures, employees in terms of age also influence the effectiveness of archive management. At a young age, employees will find it easier to adjust to electronic updates. A study in the Customs and Excise Office Type A Semarang found that employees aged 20 - 28 years old prefer to use electronic archives as it helps to quickly input any data, while employees in other aged range are not that good in adjustment to technology. The existence of electronic archives makes $80 \%$ of the employees at the Customs and Excise Type A Semarang feel more being helped by reducing paper documents that usually pile up.

The electronic archives have been implemented at the Customs and Excise Office Type A Semarang, but a conventional archive is still found. Other facts at the Ministry of Social Affairs that follows the development of the digital era including archive management. The Ministry of Social Affairs has implemented the digitalization of all archives starting in 2020. The study entitled The Influence of Implementation of a Review System in Employee Performance in Archives Management in PT. Industri Kapal Indonesia showed that the creation of archives, management, utilization, and deletion of records of the employee performance is in a good category by considering the quantity of work, quality of work, timeliness, and attendance of employees (Rajma \& Siswahyudi, 2021). Other research conducted a study entitled Analysis of Filing System Management / Correspondence in Improving Communication at PT Dirgantara Indonesia and found changes in the increase in the effectiveness of employee and superior communication by using the available features (Seprilya \& Damayanti, 2020). E-filing in Supporting Work Effectiveness of Employees and found that the use of an electronic filing system has not fully been able to support work effectiveness for employees of the Electronic Archives Management Administration Department in Indonesia study conducted by (Call et al., 2016; Syafitri et al., 2018). There are differences in the results of previous studies regarding the use of electronic records as a support for employee performance, thus, this study will re-examine these variables.

The use of an electronic archive system in an institution will certainly make it easier and profitable for users, such as improving services, save archival space, reduce the rate of loss and damage to documents, and cost-saving (Abrosimova et al., 2021; Sugiarto, A., \& Wahyono, 2005). The existence of provisions related to the completeness of an electronic archive to ensure that the contents of the archive are in a wellmaintained condition, the employee should ensure that each electronic archive has elements of intellectual form. The element cover giving sequential dates in the recipient or sender, the archive container can be done from the origin of an archive, the address of the archive sender, the subject as well as the name and signature of the author (Kriswibowo et al., 2017; Zeidan \& Liu, 2021). Many institutions or organizations have experienced the benefits of electronic archives. The benefits of using electronic archives such as a) Quickly found without leaving the work desk or wherever they are. b) To easily index, modified based on evolving procedures will save time, effort and cost. c) Full-text search is easier by searching for files based on keywords or file names and then finding them in the form of full-text documents. d) Very small chance 
of loss of files as they can only be viewed on the monitor screen or printed without changing them. e) Digital archiving, a hard document or other damage due to age can be minimized as it is stored digitally. f) Easy to share archives with clients because it can be done through the internet. g) Maximizing security so that not just anyone can access the archive. $h$ ) Data recovery is easier, backing up data to other storage media while recovering paper documents that have been burned or damaged due to other accidents will be more difficult to back up (Nyfantoro et al., 2020; Ribka Aprilia et al., 2020).

The electronic archive is beneficial for employees and institutions, but employees should consider the challenges such as a.) electronic archives can be accessed anytime and anywhere, so there are opportunities to manipulate documents, delete them very easily without leaving any traces, b.) it is difficult to share documents due to lack of network availability, or different formats to access them, c.) documents can be damaged due to the detection of a virus on the device used to store them. The use of electronic archives can streamline information processing so that it can be one of the factors to increase employee performance. Performance is a result that has been achieved by employees in carrying out their duties according to the responsibilities given in quality and quantity (Elizar \& Tanjung, 2018; Rosmaini \& Tanjung, 2019; Sriwidodo \& Haryanto, 2010). The employee performance is the number of employees who contribute to the institution and companies covering quality, quantity, attendance, cooperative attitude, and time. Employee performance is important in achieving an activity to realize a goal of the institution as it is important to increase the competitiveness of the institution (Aji Tri Budianto \& Katini, 2019; Kriswibowo et al., 2017). This study aims to analyze the use of electronic archives to support the effectiveness of employee performance and the factors supporting employee performance. The results of the study can also provide input to companies regarding the influence of the use of electronic archives on employee performance at the Customs and Excise Office Type A Semarang.

\section{METHODS}

This study is qualitative descriptive that can describe the actual object or situation systematically. Interviews are data collection techniques that propose questions orally to subjects and the interviews are open/unstructured (Sugiyono, 2018). This study used primary data obtained directly through interviews. This study used three stages of data analysis: First, data reduction, reducing data by summarizing, choosing the main things, and focusing on the important thing to look for themes and patterns (Sugiyono, 2015). Second, data model, a collection of structured information that can describe conclusions and take action (Idrus, 2009). The data presented were a reduction of the results of interviews with informants. The presentation of the data is in the form of a set of structured information and provides the possibility of drawing conclusions and taking action. Third, drawing conclusions, taking a conclusion in the form of a description that was previously still unclear so that the research becomes clear. The study was conducted in the Customs and Excise Office Type A Semarang which is located on Jl. Yos Sudarso, Tawangsari, West Semarang Sub-district, Semarang City. This study aims to identify the use of electronic archives to support employee performance at the Customs and Excise Office Type A Semarang. The selected resource persons were employees with the position of Implementing Customs and Excise Examiner with a length of service of 13 years as well as employees with the position of Implementing Examiners with different positions and an average length of service of 6-3 years.

\section{RESULTS AND DISCUSSIONS}

\section{Results}

The interviews were conducted with two approaches in which interviews with informant 1 and informant 2 were done face-to-face, while the interview with informants 3 and 4 was via Zoom meeting. The results of the interviews in table 1.

Table 1. Results of Interviews of Benefits of Electronic Archives

\begin{tabular}{|c|c|c|c|c|}
\hline No & Questions & Inforı & nants & $\begin{array}{c}\text { Summary of the } \\
\text { response }\end{array}$ \\
\hline \multirow[t]{3}{*}{1} & The use & N1 & N2 & \multirow{3}{*}{$\begin{array}{l}\text { Archives in the form } \\
\text { of file which is stored } \\
\text { and managed in } \\
\text { computer }\end{array}$} \\
\hline & $\begin{array}{l}\text { electronic } \\
\text { archives }\end{array}$ & $\begin{array}{l}\text { Archives that does not } \\
\text { need paper, in the form of } \\
\text { file }\end{array}$ & $\begin{array}{l}\text { Collected and stored in } \\
\text { the computer }\end{array}$ & \\
\hline & & N3 & N4 & \\
\hline
\end{tabular}




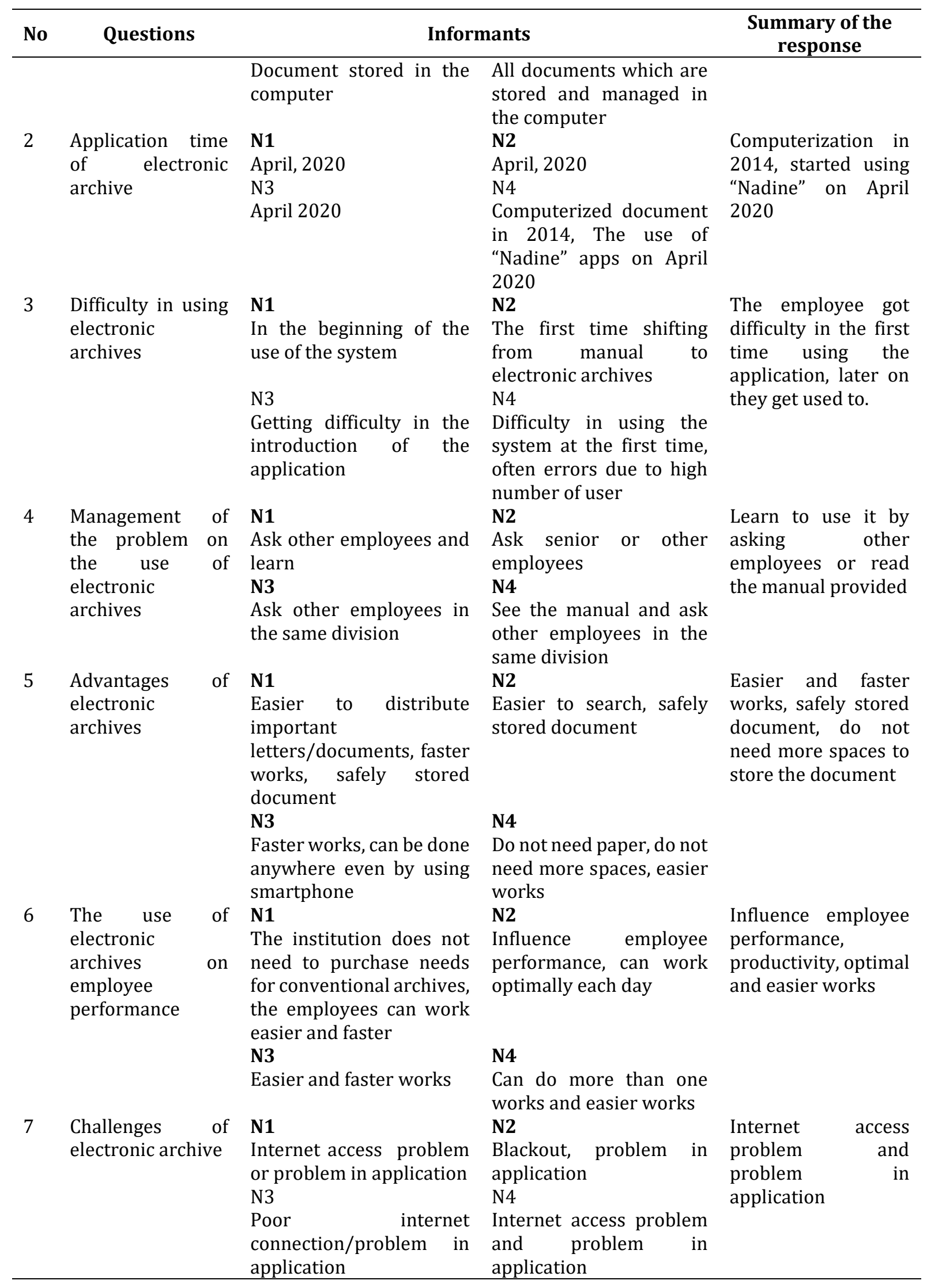

Based on table 1, the four informants gave the same answer to answer the research question of the advantages of electronic archives as supporting the performance of the employees in this institution. This study found that the benefits of electronic archives cover easier works, faster works, safely stored archives, and saving paper and space. However, if the supporting facilities are disturbed, they often experience 
problems. Besides helping employees work faster, the electronic archives also support employee performance. The results of this study are different from a study by (Irawan \& Simargolang, 2018) .They found that the benefits of implementing electronic archives cover minimizing the loss and damage of documents, getting easier in the process of searching for data and information, and providing accurate results to help the archive process in accordance with the principle. This study also explores issues regarding the factors supporting employee performance. The detailed results can be seen in Table 2 .

Table 2. Interview Results of Employee Performance

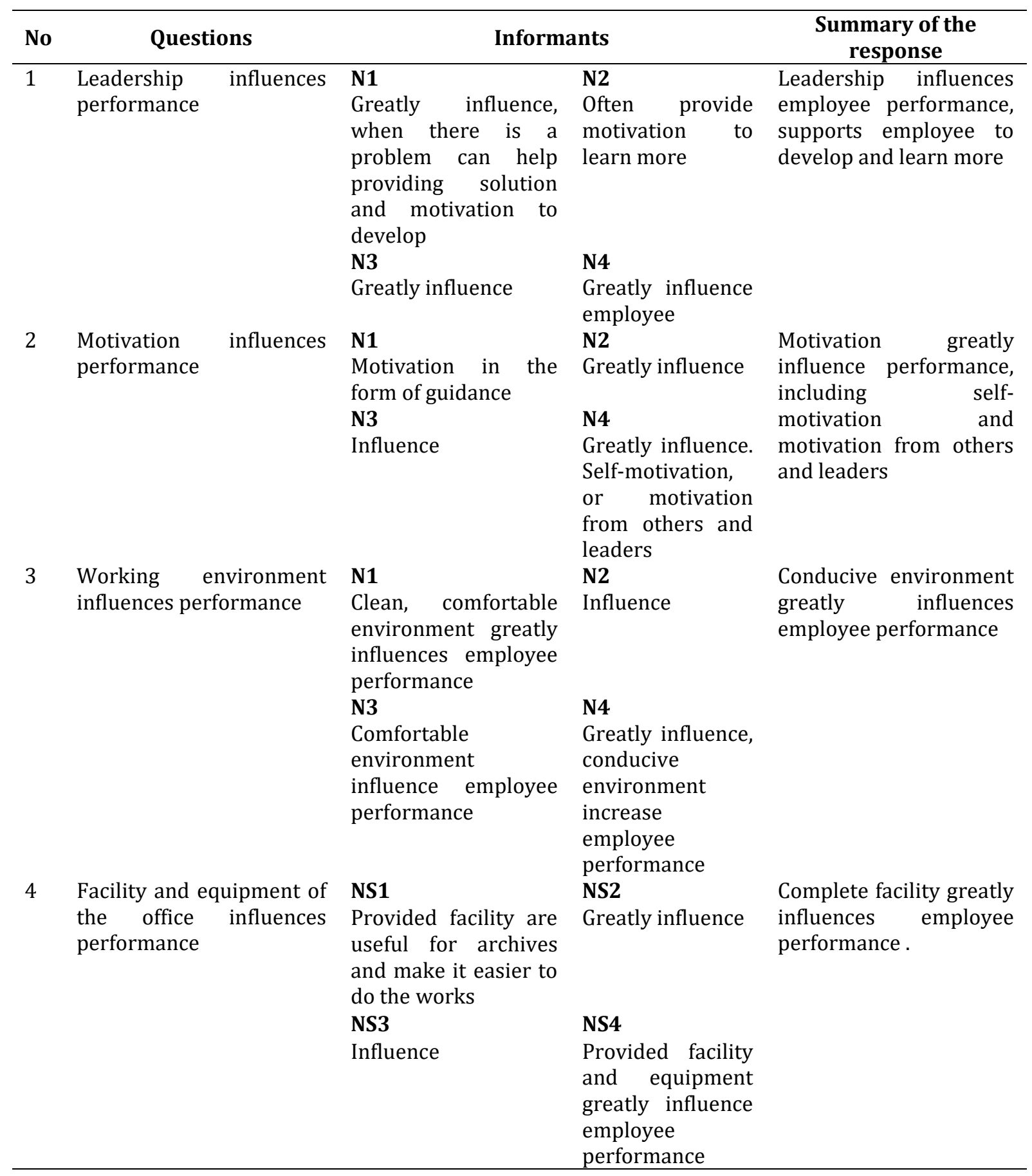

Based on table 2, the four informants gave the same answer in which the existence of leaders who always encourage employees to continue learning by facilitating training organized by the institution and comfortable environment influence the employee performance. The existence of self-motivation and motivation from coworkers increases employee performance. Furthermore, equipment and facilities provided to employees are sufficient to support their work. The results of this study are in contrast with the 
previous study by Akbar (2018) who revealed that the employee performance factors are influenced by leadership patterns, a good management system to create a work environment, and organizational productivity.

\section{Discussion}

Based on the results of interviews regarding the use of electronic archives as a support for employee performance at the Customs and Excise Office Type A Semarang, the use of electronic archives helped and facilitated them in carrying out their work. During the use of manual archives, there were difficulties in doing their work. In 2014 when using a computerized system, some hard files were still used for certain documents. The use of this computerized system makes it easier for employees to find the files needed (ElZahed \& Marzouk, 2022; Farzandipour et al., 2021). This is in line with the theory proposed by The electronic archives makes it easier for employees to search for files based on keywords and then the files can be found as a whole. Implementing electronic archive system is very easy and profitable for its users (Cartwright \& Edney, 2012; Sugiarto, Agus \& Wahyono, 2005). This present study showed that electronic archives are not only to facilitate work but also make the existence of electronic archives document storage safe, perform works quickly, as well as get efficient time and cost.

The digitizing archives guarantees efficiency in archive management, therefore digitizing a document can store for the short or long term and limit user access so that they can save copies in case of damage/disaster (Nyfantoro et al., 2020; Yakin Bakhtiar Siregar, 2019). This study found that electronic archives make it easier for users to do their work and even it can be accessed anywhere (Dascher, 2015; Luciano, 2021; Peyn \& Linke, 2018). The use of electronic archives for the institution is low cost as there is no need to add buildings to store files that have been inputted and wait for the destruction period and can reduce expenditures for other conventional archiving equipment such as purchasing folders, cabinets, paper, and so on. Electronic archives are not only useful but also support the effectiveness of employee performance. Based on the results of interviews with four informants, three of them have the same opinion that electronic archives are very effective in supporting their performance due to their ease to find and timeefficient. This is in line with the theory of performance effectiveness as a benchmark to state how far the target has been achieved. The greater the goal, the higher the level of effectiveness (Bittner, 2021; Hofverberg \& Winberg, 2020; Publika et al., 2020).

Based on the results of interviews with the four informants related to the factors supporting employee performance in using electronic archives at the Customs and Excise S Office Type A Semarang, they proposed similar responses in which they feel that they can work effectively because of the motivation from their superiors who encourage them to be active and enthusiastic in working, open to the consultation if there are difficulties or misunderstandings, and self-motivation so that they have the desire to continue learning to improve their ability to work, especially in using information technology. In increasing individual performance in carrying out tasks, there is a close relationship between task suitability and individual abilities in using information technology (Bravo et al., 2015; Hatlevik et al., 2018; Indiyaningsih et al., 2020). A study revealed that the support of supervisors and co-workers has a close relationship with the ability of employees to carry out tasks according to their abilities (Blume et al., 2010; Kurniasari, 2018; Molly et al., 2017). The environment, both physical and non-physical, is also supportive, such as cooperative co-workers and a comfortable workplace that supports daily work activities. However, the abilities possessed by employees affect work effectiveness. Therefore, employees or administrative personnel who enter this office must have the minimum standard of ability. Besides, the facilities and completeness of supporting infrastructure greatly affect the effectiveness of work as using electronic archives should be supported by good electronic devices and standard equipment, smooth internet network, adequate working environment facilities such as air-conditioned, clean, conducive rooms. The fulfillment of the motivating factors for employees in the Customs and Excise Office Type A Semarang can make employees more productive. In this present study, there are some limitations. This study only examined four employees in one Section/Division. Future studies need to examine other variables that can affect performance such as stress, productivity, and others. Future studies can also examine other objects or compare with the office in other regions, or increase the number of informants from each section in order to compare the results.

\section{CONCLUSION}

The benefits of electronic archives as a support for the effectiveness of employee performance at the Customs and Excise Office Type A Semarang cover making it easier for employees to do their work and to work fast such as completing more than one documents per day, safely storing documents, and timeefficient. Factors supporting employee performance in using electronic archives are the leader who always 
encourages employees to learn and develop themselves and a comfortable work environment for the employee, the ability of human resources, and adequate facilities and equipment provided by the institution.

\section{REFERENCES}

Abrosimova, P., Sivkov, S., Romanova, G., \& Mashkin, A. (2021). Some methods of improving the quality of electronic archives at the machine-building enterprise. Procedia Computer Science, 91. https://doi.org/10.1016/j.procs.2021.06.032.

Aji Tri Budianto, \& Katini, A. (2019). Pengaruh Lingkungan Kerja Terhadap Kinerja Pegawai Pada PT Perusahaan Gas Negara (Persero) Tbk SBU Distribusi Wilayah I Jakarta. Parameter, 4(2). https://doi.org/10.37751/parameter.v4i2.42.

Akbar, S. (2018). Analisa Faktor-Faktor Yang Mempengaruhi Kerja. Jiaganis, 3(2), 1-17.

Alarcón-Aguirre, J. S., Aguirre-Mejía, P. M., Palacios-Hinestroza, H., \& Sulbarán-Rangel, B. (2020). Evaluation of the forestry administrative system that regulates the activity of extracting wood from the Northern Ecuadorian amazon. Land Pse Policy, https: //doi.org/10.1016/j.landusepol.2020.104852.

Aryani, R., Suratno, T., Mauladi, M., \&, \& Utomo, P. E. P. (2019). Implementasi Sistem Informasi Manajemen Arsip Di Fakultas Sains dan Teknologi Universitas Jambi. Jurnal Ilmiah Media Sisfo, 146-159. https://doi.org/https://doi.org/10.33998/mediasisfo.2019.13.2.713.

Bittner, J. V. (2021). Goal interruptions and task performance: The additional influence of goal orientations. Learning and Motivation, 76. https://doi.org/10.1016/j.lmot.2021.101768.

Blume, B. D., Ford, J. K., Baldwin, T. T., \& Huang, J. L. (2010). Transfer Of Training: A meta-Analytic Review. Journal of Management, 36(4), 1065-1105. https://doi.org/10.1177/0149206309352880.

Bravo, E. R., Santana, M., \& Rodon, J. (2015). Information systems and performance: The role of technology, the task and the individual. Behaviour and Information Technology, 34(3), 247-260. https://doi.org/10.1080/0144929X.2014.934287.

Bressey, C. (2020). Surfacing black and brown bodies in the digital archive: domestic workers in late nineteenth-century Australia. Journal of Historical Geography, 70. https://doi.org/10.1016/j.jhg.2020.07.001.

Call, A. C., Kedia, S., \& Rajgopal, S. (2016). Rank and file employees and the discovery of misreporting: The role of stock options. Journal of Accounting and Economics, 2. https://doi.org/10.1016/j.jacceco.2016.06.003.

Cartwright, S. M. I., \& Edney, L. A. (2012). Ambulatory Perianesthesia Electronic Documentation-A TwoPart Series. Part II: Archiving Your Actions. Journal of PeriAnesthesia Nursing, 27(6). https://doi.org/10.1016/j.serrev.2007.03.003.

Chen, L., Li, Q., Zhao, X., Fang, Z., Peng, F., \& Wang, J. (2019). Multi-population coevolutionary dynamic multiobjective particle swarm optimization algorithm for power control based on improved crowding distance archive management in CRNs. Computer Communications, 145. https://doi.org/10.1016/j.comcom.2019.06.009.

Dascher, O. (2015). Data Bases and Statistical Systems: Archives and Historical Databases. International Encyclopedia of the Social \& Behavioral Sciences (Second Edition), 700. https: //doi.org/10.1016/B978-0-08-097086-8.62131-1.

Elizar, \& Tanjung, H. (2018). Pengaruh Pelatihan, Kompetensi, Lingkungan Kerja Terhadap Kinerja Pegawai. Maneggio: Jurnal Ilmiah Magister Manajemen, 1(1), 46-58. https://doi.org/10.30596/maneggio.v1i1.2239.

ElZahed, M., \& Marzouk, M. (2022). Smart archiving of energy and petroleum projects utilizing big data analytics. Automation in Construction, 133. https://doi.org/10.1016/j.autcon.2021.104005.

Farzandipour, M., Jabali, M. S., Nickfarjam, A. M., \& Tadayon, H. (2021). Usability evaluation of selected picture archiving and communication systems at the national level: Analysis of users' viewpoints. International Journal of Medical Informatics, 147. https://doi.org/10.1016/j.ijmedinf.2020.104372.

Fauziyah, L. G. (2019). Pengelolaan Arsip Dinamis Oleh Pegawai Di Kantor Kepala Desa Lumbung Kecamatan Lumbung Kabupaten Ciamis. Dinamika: Jurnal Ilmu Administrasi Negara, 6(2). https://doi.org/10.25157/dinamika.v6i2.2282.

Habiburrahman. (2016). Penggunaan Perangkat Lunak Dalam Pengelolaan Arsip Konvensional Dan Elektronik. Jurnal Ilmu Perpustakan Dan Informasi, 1(2). https://doi.org/10.30829/jipi.v1i2.559.

Hatlevik, O. E., Throndsen, I., Loi, M., \& Gudmundsdottir, G. B. (2018). Students' ICT self-efficacy and computer and information literacy: Determinants and relationships. Computers and Education, 118, 107-119. https://doi.org/10.1016/j.compedu.2017.11.011. 
Hodder, J., Heffernan, M., \& Legg, S. (2021). The archival geographies of twentieth-century internationalism: Nation, empire and race. Journal of Historical Geography, 71. https://doi.org/10.1016/j.jhg.2020.06.008.

Hofverberg, A., \& Winberg, M. (2020). Achievement goals and classroom goal structures: Do they need to match? Journal of Educational Research, 113(2), 145-162. https://doi.org/10.1080/00220671.2020.1759495.

Idrus, M. (2009). Metode Penelitian Ilmu Sosial. Erlangga.

Indiyaningsih, K. M. H., Murdyastuti, A., \& Puspitaningtyas, Z. (2020). Efeect of human resource competency, work culture and utilization of information technology to performance of employees. International Journal of Scientific and Technology Research, 9(4), 3636-3641. https://doi.org/10.19184/issrd.v2i1.17468.

Irawan, M. D., \& Simargolang, S. A. (2018). Implementasi E-Arsip Pada Program Studi Teknik Informatika. Jurnal Teknologi Informasi, 2(1), 67. https://doi.org/10.36294/jurti.v2i1.411.

Kalinda, L. (2019). Pengelolaan Arsip Berbasis Digital Oleh Pegawai Di Kantor Pengadilan Agama Ciamis. Dinamika: Jurnal Ilmu Administrasi Negara, 6(3). https://doi.org/10.25157/dinamika.v6i3.2811.

Kiklhorn, D., Wolny, M., Austerjost, M., \& Michalik, A. (2020). Digital lifecycle records as an instrument for $\begin{array}{lllll}\text { inter-company } & \text { knowledge } & \text { management. }\end{array}$ https://doi.org/10.1016/j.procir.2020.03.062.

Kothari, U. (2021). Seafarers, the mission and the archive: Affective, embodied and sensory traces of seamobilities in Melbourne, Australia. Journal of Historical Geography, 71. https://doi.org/10.1016/j.jhg.2021.05.003.

Kriswibowo, A., Harsanto, B. T., \& Kurniasih, D. (2017). Upaya Meningkatkan Kinerja Pegawai Kantor Perpustakaan Dan Arsip Daerah Kabupaten Banyumas. Jurnal Dinamika Governance, 7(2). https://doi.org/10.33005/jdg.v7i2.1205.

Kulcu, O., \& Cakmak, T. (2012). Convergence of the Records Management and Enterprise Content Management in the Digital Environment. Procedia - Social and Behavioral Sciences, 62. https://doi.org/10.1016/j.sbspro.2012.09.031.

Kurniasari, R. (2018). Pemberian Motivasi serta Dampaknya Terhadap Kinerja Karyawan Pada Perusahaan $\begin{array}{lllll}\text { Telekomunikasi Jakarta. } & \text { Widya } & \text { 32-39. }\end{array}$ https://doi.org/10.31294/widyacipta.v2i1.2551.

Liu, X.-F., Zhou, Y.-R., Yu, X., \& Lin, Y. (2019). Dual-archive-based particle swarm optimization for dynamic optimization. Applied Soft Computing, 85. https://doi.org/10.1016/j.asoc.2019.105876.

Luciano, E. (2021). On Francesco G. Tricomi's heritage: Archive and miscellany. Historia Mathematica, 56. https://doi.org/10.1016/j.hm.2021.05.001.

Mikhail, P., Andrey, K., Igor, K., \& Mikhail, S. (2018). Optimization of electronic document management systems by means of encoding and visualization of stored data in the integrated development environment. Matec Web of Conferences, 228. https://doi.org/10.1051/matecconf/201822604021.

Molly, B., Tanaamah, A. R., \& Sitokdana, M. N. N. (2017). Analisis Kinerja Sistem Informasi dan Teknologi Informasi untuk Menunjang Kinerja Karyawan Menggunakan Framework IT Balanced Scorecard (Studi Kasus pada Wi-Fi Universitas Kristen Satya Wacana). Jurnal Teknologi Informasi Dan Ilmu Komputer, 4(4). https://doi.org/10.25126/jtiik.201744499.

Mufidah, Y. A. (2013). Efektivitas Kerja Pegawai Dalam Penggunaan Sistem Kearsipan Elektronik Di Kantor Badan Arsip Dan Perpustakaan Kota Surabaya. Jurnal Pendidikan Administrasi Perkantoran, 1(03). https://doi.org/10.1074/jbc.271.41.25173

Nugraha, D. A. (2019). Pengelolaan Kearsipan Berbasis Elektronik Di Dinas Perpustakaan Dan Kearsipan Kabupaten Ciamis. Dinamika: Jurnal Ilmu Administrasi Negara, 6(4). https://doi.org/10.25157/dinamika.v6i4.3089.

Nyfantoro, F., Salim, T. A., \& Mirmani, A. (2020). Perkembangan Pengelolaan Arsip Elektronik Di Indonesia: Tinjauan Pustaka Sistematis. Diplomatika: Jurnal Kearsipan Terapan, 3(1), 1. https://doi.org/10.22146/diplomatika.48495.

Peyn, T., \& Linke, S. (2018). The Dräger Company Archives - Collecting, Preserving and Researching Remarkable Dräger Items, Photos and Documents to Save Them for Later Generations. Journal of Anesthesia History, 4(1). https://doi.org/10.1016/j.janh.2017.11.007.

Przybyła, K., Kachniarz, M., \& Ramsey, D. (2020). The investment activity of cities in the context of their administrative status: A case study from Poland. Cities, 97. https://doi.org/10.1016/j.cities.2019.102505.

Publika, J., Cirebon, U., Sunandar, A., Wulandari, S., Negara, I. A., Swadaya, U., \& Jati, G. (2020). Pengaruh Fungsi Pembagian Kerja Terhadap Efektivitas Kerja Pegawai Pada Badan Kepegawaian dan 
Pengembangan Sumber Daya Manusia Kabupaten Cirebon. Jurnal Ilmiah Publika, 7, 68-82. https://doi.org/10.33603/publika.v7i2.4144.

Rajma, S., \& Siswahyudi, N. (2021). The Influence of Implementation of a Review System on Employee Performance in Archives Management in PT . Industri Kapal Indonesia. 3(1), 83-92. https://doi.org/https://ojs.unm.ac.id/PBAR/article/view/24114.

Ribka Aprilia, M, A. Y., \& Arif, L. (2020). Efektivitas Pengelolaan Arsip Elektronik Di Indonesia. Jurnal Syntax Transformation, 1(3). https://doi.org/10.46799/\%25J.Vol1.Iss3.30.

Rifauddin, M. (2016). Pengelolaan Arsip Elektronik Berbasis Teknologi. Khizanah Al-Hikmah: Jurnal Ilmu Perpustakaan, Informasi Dan Kearsipan, 4(2). https://doi.org/10.24252/kah.v4i27.

Rosmaini, R., \& Tanjung, H. (2019). Pengaruh Kompetensi, Motivasi Dan Kepuasan Kerja Terhadap Kinerja Pegawai. Maneggio: Jurnal Ilmiah Magister Manajemen, 2(1). https://doi.org/10.30596/maneggio.v2i1.3366.

Rustam, M. (2014). Pengelolaan Arsip Elektronik (Cetakan Ke). Universitas Terbuka.

Seprilya, N., \& Damayanti, F. (2020). Analisis Pengelolaan "Filing System (Tata Persuratan) Dalam Meningkatkan Efektivitas Komunikasi di PT Dirgantara Indonesia” 1). Jurnal Sekretaris Dan Administrasi Bisnis, IV(2), 157-168. https: //doi.org/https://doi.org/10.31104/jsab.v4i2.193.

Sholeh, M., \& Hartono. (2018). Pengelolaan Arsip Berbasis Digital Dengan Menggunakan Tanda Tangan Elektronik Dan Implementasi Aplikasi Arsip Menggunakan Marteri. Jurnal Dharma Bhakti, 1.

Şimşek, T., Öner, M. A., Kunday, Ö., \& Olcay, G. A. (2022). A journey towards a digital platform business model: A case study in a global tech-company. Technological Forecasting and Social Change, 175. https://doi.org/10.1016/j.techfore.2021.121372.

Sreemany, A., \& Bera, M. K. (2022). Does a large delta-fan sedimentary archive faithfully record floodplain vegetation composition? Quaternary Science Reviews, 228. https://doi.org/10.1016/j.quascirev.2019.106108.

Sriwidodo, U., \& Haryanto, A. B. (2010). Pengaruh Kompetensi, Motivasi, Komunikasi dan Kesejahteraan Terhadap Kinerja Pegawai Dinas Pendidikan. Manajemen Sumberdaya Manusia, 4(1).

Sugiarto, A., \& Wahyono, T. (2005). Manajemen Kearsipan Modern. Gava Media.

Sugiarto, Agus \& Wahyono, T. (2005). Manajemen Kearsipan Modern dari Konvensional ke Basis Komputer. Gava Media.

Sugiyono. (2015). Metode Penelitian Kombinasi (Mix Methods). alfabeta.

Sugiyono. (2018). Metode Penelitian Kuantitatif,Kualitatif dan R\&D. In ke-26.

Syafitri, E. M., Priyanto, \& Indrasari, F. (2018). E-filling Dalam Menunjang Efektivitas Kerja Karyawan. Epichirisi, Jurnal Manajemen, Administrasi, Pemasaran Dan Kesekretariatan, 2(2), 1-8. https://doi.org/http://journal.pnm.ac.id/index.php/epicheirisi/article/view/307.

Tray, E., Leadbetter, A., Meaney, W., Conway, A., Kelly, C., \& Maoiléidigh, N. Ó. (2020). An open-source database model and collections management system for fish scale and otolith archives. Ecological Informatics, 59. https://doi.org/10.1016/j.ecoinf.2020.101115.

Triyono, T., \& Samopa, F. (2013). Pembuatan Sistem Informasi Penatausahaan Surat dan Arsip Berbasis Web Studi Kasus Kantor Pelayanan Perbendaharaan Negara Bengkulu. Jurnal Teknik ITS. https://doi.org/10.12962/j23373539.v2i2.4831.

Yakin Bakhtiar Siregar. (2019). Digitalisasi Arsip Untuk Efisiensi Penyimpanan. Jurnal Administrasi Dan Kesekretarisan, 4,1-19. https://doi.org/10.36914/jak.v4i1.192.

Zeidan, A., \& Liu, E. L. (2021). Practical Aspects of Point-of-Care Ultrasound: From Billing and Coding to Documentation and Image Archiving. Advances in Chronic Kidney Disease, 28(3). https://doi.org/10.1053/j.ackd.2021.06.004. 